\title{
SEJARAH UANG REPUBLIK INDONESIA BANTEN (URIDAB) (1945-1949)
}

\author{
The History of Uang Republik Indonesia Banten (Uridab) 1945-1949
}

\author{
Oleh Lasmiyati \\ Balai Pelestarian Nilai Budaya Bandung, \\ Jl. Cinambo 136 Ujungberung Bandung Telepon/fax: 022 - 7804942, \\ email : lasmiyatinizam@gmail.com
}

Naskah Disetujui: 30 Agustus

\begin{abstract}
Abstrak
Setelah Kemerdekaan Indonesia diproklamasikan tanggal 17 Agustus 1945, di Serang Banten terdapat dua peristiwa penting, yaitu revolusi sosial dan tempat pencetakan uang daerah untuk Banten. Tahun 1947, di Serang, tentara Belanda di bawah naungan Pasukan Sekutu melakukan blokade darat dan laut. Pemerintahan di Serang pun putus komunikasi dengan Pemerintah RI yang berada di Yogyakarta. Agar perekonomian di Serang tetap berjalan, pemerintah pusat mengizinkan daerah Banten untuk mencetak uang daerah sendiri bernama Uang Republik Indonesia Daerah Banten (URIDAB). Menjadi pertanyaan tersendiri mengapa Serang Banten dipercaya oleh pemeritah pusat untuk mencetak uang dan mengapa pasukan Belanda melakukan blokade ekonomi. Tujuan penelitian ini untuk mengetahui mengapa Serang Banten dipercaya oleh pemerintah pusat untuk mencetak uang sendiri, adakah hubungannya antara URIDAB dan revolusi sosial. Metode yang digunakan adalah metode sejarah yang meliputi empat tahapan yaitu heuristik, kritik, interpretasi, dan historiografi. Melalui hasil penelitian yang dilakukan, diketahui bahwa pencetakan uang daerah di Banten diawali dengan perpindahan ibu kota RI dari Jakarta ke Yogyakarta. Belanda yang datang ke Indonesia dengan cara membonceng NICA melakukan kekacauan, penyerangan, dan memblokade ekonomi. Daerah-daerah yang lokasinya jauh dengan ibu kota RI sangat kesulitan berkomunikasi, sehingga pemerintah pusat yang berkedudukan di Yogyakarta memberikan wewenang kepada Residen Banten Achmad Chatib untuk mencetak mata uang sendiri dengan nama URIDAB kepanjangan dari Uang Republik Indonesia Daerah Banten.
\end{abstract}

Kata kunci: sejarah, uang daerah Banten. 


\begin{abstract}
There were two important things that happened in Serang (Banten) after the Indonesian independence was proclaimed on August 17, 1945: social revolution, and printing of money for Banten. In 1947 the Dutch army under the protection of the Allies blockaded either land and sea, cutting off communications between central (Yogyakarta) and regional (Serang) government. The central government in Yogyakarta gave permission to Serang to print money so that economic activity could still be running. The money was called URIDAB (Uang Republik Indonesia Daerah Banten, or the money of the Republic of Indonesia in Banten). The research questions are why central government gave permission to Banten to print money and why the Dutch army blockaded the economy. To answer these questions the author conducted histoy methods: heuristic, critique, interpretation, and historiography. Research finds that when the capital of Indonesia moved from Jakarta to Yogyakarta during the Dutch military aggression, communications were cut off and it was difficult for central government in Yogyakarta to make contact to regional governments. Therefore, the central government authorized the Resident of Banten, Achmad Chatib, to print its own money.
\end{abstract}

Keywords: history, the money of Banten.

\section{A. PENDAHULUAN}

Setelah proklamasi kemerdekaan dibacakan oleh Ir. Soekarno di Pegangsaan Timur Jakarta, di Banten terjadi dua peristiwa, yaitu perebutan kekuasaan dari tangan Jepang dan revolusi sosial. Perebutan kekuasaan dari tangan Jepang terjadi berupa penurunan bendera Jepang di hotel Vos Serang (yang sekarang menjadi kantor Kodim Serang) yang diprakarsai oleh Sri Sahuli. Para pemuda Banten juga melucuti senjata dan merebut kekuasaan pemerintahan dari orang-orang Jepang. Dengan adanya kejadian tersebut orang Jepang Sakura yaitu orang Jepang dari kalangan sipil yang mengenakan lencana sakura mulai meninggalkan Serang. Kepergian mereka diikuti pamongpraja yang berasal dari Priangan, mereka meninggalkan Serang karena khawatir akan menjadi amukan pemuda Banten. Dengan kepergian beberapa orang Jepang dari Serang tersebut, Residen Banten yang diisi oleh orang Jepang Yukii Yoshii menyerahkan jabatannya kepada wakilnya Tirtasudira, namun Tirtasudira ikut melarikan diri dari Banten. Adapun revolusi sosial yang terjadi di Serang Banten karena ada keinginan dari $\mathrm{Ce}$ Mamat menjadi dewan rakyat. Keinginan $\mathrm{Ce}$ Mamat didukung oleh rakyat yang menginginkan perubahan, bahwa jabatan bupati tidak diisi oleh orang-orang lama melainkan diisi oleh orang-orang baru. Kemudian mereka menuju kantor keresidenan untuk melakukan pendudukan. Aksi Ce Mamat dan pengikutnya dapat diredam oleh Bupati Serang Kyai Syam'un.

Bulan September 1945, dua divisi Australia dari pasukan Sekutu memasuki Kalimantan dan Indonesia Timur, tiga divisi Inggris menduduki Jawa dan Sumatera untuk mengurus 350.000 tentara Jepang dan beberapa ratus ribu interniran Sekutu (Nasution, 1977: 3). Tentara NICA yang ikut dalam rombongan tersebut merupakan tentara Belanda yang berkeinginan menjajah kembali, mereka melakukan teror dan kekacauan. Sikap tentara NICA menimbulkan perlawanan dari para pejuang khususnya di Banten. Dalam menguasai daerah Banten, pasukan Sekutu melakukan blokade ekonomi. Dengan permasalahan tersebut yang menjadi 
pertanyaan adalah mengapa Belanda melakukan blokade ekonomi dan apa dampak dari adanya blokade tersebut. Berdasarkan masalah tersebut penelitian ini bertujuan untuk menjawab atas masalah mengapa Belanda melakukan blokade ekonomi dan apa dampak adanya blokade tersebut.

Dalam tulisan ini ada satu buah rujukan yang dapat dijadikan acuan, yaitu pengertian mengenai uang. Uang dapat digunakan untuk memenuhi segala kebutuhan manusia. Menurut Sugono, uang adalah alat tukar atau standar pengukur nilai (kesatuan hitungan) yang sah, dikeluarkan oleh pemerintah suatu negara berupa kertas, emas, perak, atau logam lain yang dicetak dengan bentuk dan gambar tertentu (Moeliono, 2011: 1512). Secara luas uang dapat diterima secara umum sebagai alat pembayaran utang atau sebagai alat untuk melakukan pembelian barang dan jasa. Dengan kata lain uang merupakan alat yang dapat digunakan dalam melakukan pertukaran baik barang maupun jasa dalam suatu wilayah tertentu saja (Kasmir, 2012: 13). Setelah pemerintah mengeluarkan uang, uang tersebut menjadi alat tukar yang dapat diterima oleh umum, yaitu seseorang dapat menukarkan uang dengan benda yang diinginkan, hal itu seperti pendapat D.H. Robertson dalam bukunya Money, disebutkan bahwa uang adalah segala sesuatu yang bisa diterima umum dalam pembayaran untuk mendapatkan barang-barang. Menurut R.G. Thomas dalam bukunya Our Modern Banking, uang adalah segala sesuatu yang siap sedia dan secara umum diterima sebagai alat pembayaran pembelian barang-barang dan jasa-jasa serta kekayaan berharga lainnya untuk membayar utang.

Dalam segi perdagangan uang mempunyai peranan sangat penting. Untuk mendapat sesuatu yang dibutuhkan tanpa pertukaran secara barter (barang dengan barang). Uang juga mempunyai peranan sebagai satuan hitung, yaitu untuk menunjukkan nilai barang atau jasa, menghitung nilai kekayaan dan pinjaman.
Hal itu seperti pendapat A.C. Pigou dalam bukunya The Veil of Money, yang dimaksud uang adalah segala sesuatu yang umum dipergunakan sebagai alat tukar. Uang mempunyai satu tujuan fundamental dalam sistem ekonomi, yaitu memudahkan pertukaran barang dan jasa; mempersingkat waktu dan usaha yang diperlukan untuk melakukan perdagangan. Selain itu, uang juga digunakan sebagai alat penyimpan dan pemindah kekayaan. Dengan uang, kekayaan berbentuk tanah dan gedung, dapat dipindah ke pemilikannya. Uang dapat berfungsi sebagai standar untuk melakukan pembayaran jangka panjang atau pencicilan pembayaran utang.

Menurut jenisnya uang dapat dibedakan dalam dua bentuk, yaitu uang kartal adalah alat bayar yang sah dan wajib digunakan oleh masyarakat dalam melakukan transaksi, dan uang giral adalah uang yang dimiliki masyarakat dalam bentuk deposito (simpanan). Untuk menarik uang tersebut menggunakan cek, masyarakat mempunyai hak untuk menolak apabila tidak mau melakukan transaksi, dibayar dengan uang tersebut. Dilihat dari bahan pembuatannya terbagi menjadi dua yaitu, uang logam dan uang kertas. Uang logam terbuat dari logam, biasanya dari emas atau perak, nilai tukarnya berdasarkan nilai nominal yang tercantum pada mata uang tersebut (http://duniabaca.com). Uang kertas adalah uang yang terbuat dari kertas dengan gambar dan cap tertentu dan merupakan alat pembayaran yang sah. Menurut penjelasan UU No. 23 tahun 1999 tentang Bank Indonesia, yang dimaksud dengan uang kertas adalah uang dalam bentuk lembaran yang terbuat dari bahan kertas atau bahan lainnya (yang menyerupai kertas).

Metode yang digunakan adalah metode sejarah, yang meliputi beberapa tahap. Tahap heuristik, yaitu tahap mencari dan menemukan sumber, baik sumber primer maupun sekunder. Langkah berikutnya melakukan kritik sumber tujuannya untuk mengetahui apakah dari sumbersumber tersebut akurat atau relevan dengan 
masalah. Setelah sumber-sumber dikritik baik ekstern maupun intern, langkah berikutnya sumber diolah untuk mendapatkan data yang akan diperlukan. Setelah data terkumpul kemudian diklasifikasi disesuaikan dengan sub bab yang akan ditulis. Langkah berikutnya adalah interpretasi, baru kemudian dilakukan penulisan atau historiografi, yaitu merangkaikan fakta hingga menjadi tulisan sejarah. Ruang lingkup penelitian secara spasial adalah daerah Keresidenan Banten dan secara temporal meliputi kurun waktu antara tahun 1945-1949.

\section{B. HASIL DAN BAHASAN}

Tanggal 17 Agustus 1945 Ir. Soekarno membacakan teks proklamasi kemerdekaan di Jalan Pegangsaan Timur 46 Jakarta, berita tersebut hanya didengar oleh sebagian kecil masyarakat yang memiliki radio. Mereka kemudian menyampaikannya kepada kawan atau masyarakat yang lain dari mulut ke mulut. Pemuda Banten yang berada di Jakarta seperti Pandu Kartawiguna, Ibnu Parna, Abdul Muluk, dan Aziz diutus oleh Chaerul Saleh menyampaikan berita proklamasi tersebut kepada tokoh masyarakat di Serang, seperti K.H. Achmad Chatib, K.H. Sjam'un, Zulkarnaen Surya Legawa Ali Amangku, Ayib Dzuhri, Entol Ternaya, dan Muhamad Masyur (Ce Mamat). Berita proklamasi tersebut baru diterima oleh masyarakat Banten tanggal 20 Agustus 1945.

Tanggal 18 Agustus 1945, Panitia Persiapan Kemerdekaan Indonesia mengesahkan Undang-Undang Dasar 1945 (Nasution, 1977: 217), Berdasarkan pasal 18 Undang-Undang Dasar 1945 berikut Pasal I dan II Aturan Peralihan UUD RI jo Peraturan Pemerintah Nomor 2/1945, wilayah Jawa Barat menjadi daerah otonom provinsi yang dikepalai oleh seorang gubernur. Provinsi dibagi dalam keresidenan-keresidenan, masing-masing dikepalai oleh seorang residen. Selanjutnya tiap keresidenan dibagi lagi atas kabupaten-kabupaten dan kotapraja yang diperintah oleh bupati dan walikota (Ekadjati, 1993: 400). Pada tahun-tahun awal kemerdekaan Provinsi Jawa Barat terdiri atas lima keresidenan, yaitu Banten, Jakarta, Priangan, Bogor, dan Cirebon. Keresidenan Banten terdiri atas Kabupaten Serang, Lebak, dan Pandeglang. Bupati yang ditunjuk atau diangkat oleh pemerintah pusat maupun oleh KNID adalah R. Hilman Djajadiningrat sebagai bupati Serang, kemudian diganti K.H. Syam'un. Tb. Hasan sebagai bupati Lebak, dan KHA Halim sebagai bupati Pandeglang. Meskipun para bupati sudah diangkat dan menempati wilayahnya masing-masing, namun belum bekerja sepenuhnya sebagai bupati, sebab masih memprioritaskan pada perebutan kekuasaan dari tangan Jepang, selain itu para pejabat tersebut juga sebagai pejuang yang aktif ikut langsung dalam perjuangan kemerdekaan.

Pasca proklamasi kemerdekaan, situasi di Serang belum sepenuhnya aman, di sana masih ada perebutan kekuasaan dari tangan Jepang. Dengan adanya kekosongan kekuasaan dalam jabatan Residen Banten, para pemuda segera membentuk Angkatan Pemuda Indonesia di Serang Banten yang diketuai oleh Ali Amangku dengan anggota Makhadi dan Achmad Mudjini M. Mereka mengadakan pertemuan dengan tokoh masyarakat Banten di rumah Zulkarnaen. Tokoh-tokoh tersebut di antaranya Kiai Haji Achmad Khatib, KH Sjam'un, Ali Amangku, Zulkarnaen Surya Kartalegawa. Pertemuan tersebut membahas tentang:

1. Pengambilalihan kekuasaan dari tangan Jepang kepada Zulkarnaen Surya Kartalegawa.

2. Masalah keamanan diserahkan kepada K.H. Achmad Chatib.

3. Urusan yang berhubungan dengan badan-badan perjuangan atau organisasi perjuangan pemuda diserahkan kepada Ali Amangku dan API (Mihrob, Chudari 1993: 238).

Dengan adanya perundingan tersebut, para pemuda mengusulkan kepada 
pemerintah pusat agar segera mengangkat K.H. Achmad Chatib sebagai Residen Banten. Usulan pemuda Banten disambut baik oleh pemerintah pusat, tanggal 19 September 1945 K.H. Achmad Chatib secara resmi diangkat oleh Ir Sukarno sebagai Residen Banten. Setelah menjabat sebagai residen, K.H. Achmad Chatib menyusun staf pemerintahan keresidenan yang terdiri atas, residen: K.H. Achmad Chatib, wakil residen: Dzoelkarnaen Soeria Karta Legawa. K.H. Sjam'un diserahi tugas untuk mengurus BKR dan badan-badan perjuangan lainnya. Untuk jabatan bupati, K.H. Achmad Chatib mempertahankan bupati-bupati lama yaitu Raden Hilman Djajadiningrat sebagai bupati Serang, Mr. Djuhana sebagai bupati Pandeglang, dan $\mathrm{R}$. Hadiwinangun sebagai Bupati Lebak. Sementara itu, jabatan-jabatan dalam bidang KNI di setiap kabupaten yaitu Serang, Pandeglang, dan Lebak diserahkan kepada daerah masing-masing, Ce Mamat untuk Kabupaten Serang, Muhamad Ali untuk Kabupaten Pandeglang, dan Raden Djajarukmana untuk Kabupaten Lebak. Rupanya sebagian rakyat Banten tidak menginginkan pengangkatan pejabat lama, mereka menginginkan pengangkatan pejabat baru, menurutnya pejabat lama merupakan alat kolonial. Di bawah pimpinan Ce Mamat rakyat mengambil alih kekuasaan terhadap pemeritahan Banten (www.blok-anak-sekolah.blogspot.com). Ce Mamat beserta pengikutnya yang menggandeng rakyat mendatangi kantor Residen Banten. Di kantor residen Ce Mamat membawa barang milik pemerintah untuk dibawa ke Ciomas, ia akan memindahkan ibu kota Kabupaten Serang ke Ciomas. Dalam suasana yang semakin keruh tersebut, bekas Daidanco K.H. Syam'un beserta kelompok ulama berhasil membentuk barisan TKR dan berhasil menumpas kelompok Ce Mamat. Suasana di kalangan pemerintahan tetap goncang karena para pamongpraja telah meninggalkan Serang.
Pada 29 September 1945 pasukan Sekutu yang dipimpin oleh van Mook dan van der Plas mendarat di Jakarta dan Surabaya. Kedatangan mereka berniat untuk menguasai lagi Indonesia. Kedatangan tentara Sekutu tidak menjadikan Indonesia menjadi tenang justru sebaliknya, tentara NICA dan tentara KNIL yang telah dipersenjatai sengaja membuat kekacauan, sehingga memancing timbulnya perlawanan dari pihak TKR dan barisan pejuang. Pada November 1945 Tentara Belanda dibawah naungan Tentara Sekutu memutuskan urat nadi perekonomian dan peredaran mata uang. Mereka juga melakukan blokade laut, dengan alasan:

1. Untuk mencegah masuknya senjata dan alat-alat militer ke Indonesia.

2. Mencegah dikeluarkannya hasil-hasil perkebunan milik Belanda dan milik asing lainnya.

3. Melindungi bangsa Indonesia dari tindakan dan perbuatan-perbuatan yang dilakukan oleh bukan bangsa Indonesia (Notosusanto, 1975: 216).

Selain Tentara Belanda melakukan blokade ekonomi, Belanda berharap dengan memblokade lewat ekonomi dapat menimbulkan keadaan sosial yang buruk dan kekurangan bahan-bahan impor. Tentara Belanda juga menghancurkan dan membumihanguskan barang-barang milik Republik Indonesia. Belanda ingin perbendaharaan Republik Indonesia kosong, sedangkan pengeluaran negara semakin besar, dan secara ekonomis Republik Indonesia akan segera bangkrut.

Pada November 1945, di Kota Jakarta sebagai ibu kota Republik Indonesia tempat kedudukan pemerintah RI tidak dapat dijamin. Tentara NICA di bawah lindungan tentara Sekutu mengadakan patroli dan bersikap bermusuhan terhadap masyarakat Republik Indonesia dan segala yang berbendera merah putih. Tentara NICA melakukan kerusuhan, teror, dan penculikan. Mereka 
tidak segan-segan melakukan teror kepada pemimpin bangsa, mengadakan patroli, menggeledah rumah-rumah, dan menyita mobil-mobil yang lewat, menurut mereka mobil-mobil tersebut milik Belanda sebelum perang (Sastrosatomo, 1987: 201). Dalam suasana demikian para pemimpin negara tidak dapat melaksanakan tugasnya dengan tenang, karena itu Yogyakarta dianggap memungkinkan untuk dijadikan ibu kota dan pusat pemerintahan. Tanggal 4 Januari 1946 Yogyakarta menjadi pusat kelangsungan kehidupan bernegara (Kutoyo, 1997: 332).

Pindahnya ibu kota Negara Republik Indonesia ke Yogyakarta mendorong pula berpindahnya sekian banyak orang, tidak hanya pemimpin dan pegawai tetapi juga instansi dan jawatan pemerintah (Kutoyo, 1997: 338), kecuali Kementerian Pedidikan dan Kebudayaan berkedudukan di Surakarta, dan Perdana Menteri Sutan Syahrir tetap tinggal di Jakarta. Bersamaan dengan berpindahnya ibu kota RI ke Yogyakarta, kondisi keuangan negara sedang kosong. Dalam usaha mengatasi kekosongan keuangan, pemerintah Indonesia melakukan pinjaman nasional. Pinjaman yang dilakukan pemerintah mendapat persetujuan dari Badan Pekerja Komite Nasional Indonesia Pusat (BPKNIP). Menteri Keuangan, Ir. Surachman melaksanakan pinjaman nasional dengan Undang-Undang No. 4/1946 sebesar Rp. 1.000.000.000,- dibagi dalam 2 tahap dan pinjaman akan dibayar kembali selambatlambatnya 40 tahun. Selain melakukan pinjaman, seluruh penduduk di Jawa dan Madura diwajibkan menyetor uangnya ke Tabungan Pos atau rumah-rumah pegadaian. Pinjaman nasional tahap pertama berhasil dikembalikan sejumlah Rp. 500.000.000 dan langkah ini dianggap berhasil.

Kesulitan untuk mengatasi kosongnya kas pemerintah belum teratasi, pihak pasukan Serikat Letnan Jenderal Sir Montaga Stopford panglima baru AFNEI memberlakukan uang NICA. (Kertoraharjo, 2009: 64-65). Dalam situasi yang tidak stabil, mata uang NICA juga tidak bisa didapat di setiap daerah, apalagi kondisi peperangan melawan Sekutu melanda di beberapa kota besar, seperti Jakarta, Yogyakarta, Semarang, Bandung dan kotakota besar lainnya. Kondisi peperangan tidak hanya terjadi di Pulau Jawa melainkan juga terjadi di Pulau Sumatera, seperti Medan dan Palembang. Dalam situasi seperti itu Belanda tetap memberlakukan mata uang NICA. Uang NICA pun menjadi alat pembayaran yang sah. Daerah-daerah yang berada dalam pendudukan NICA diberlakukan uang NICA, orang-orang yang bekerja pada Belanda juga mendapatkan gaji dengan mata uang NICA. Di daerah-daerah yang dilanda peperangan melawan pasukan Sekutu mulai kesulitan untuk mendapatkan uang NICA, begitu pula di daerah-daerah pedesaan. Di pedesaan mata uang yang beredar adalah mata uang Jepang, sebab orang yang berada di pedesaan baik itu pedagang atau pun petani hanya menerima uang Jepang sebagai alat pembayaran yang sah. Dengan adanya ketidakseragaman antara mata uang yang berlaku di kota-kota besar dan yang ada di daerah, maka dua mata uang yang berlaku tersebut sangat menyulitkan masyarakat, sebab orang yang mendapat gajinya dengan uang NICA, tidak dapat dibelanjakan pada petani yang hanya mau menerima pembayarannya dengan uang Jepang, sehingga uang NICA tidak dapat dibelanjakan dan ditukarkan dengan barang yang diinginkan. Uang NICA pun di pedesaan susah didapat, begitu pula dengan uang Jepang di tempat pendudukan Belanda. Kesulitankesulitan pun mulai muncul seperti diantaranya barang-barang dari pedesaan susah didistribusikan ke tempat lain, sedangkan daerah-daerah lain sangat membutuhkan barang-barang dari pedesaan. Akibatnya barang susah didapat sedangkan kebutuhan terus meningkat, dampaknya harga barang-barang terus melambung. Dengan adanya kesulitan seperti inilah maka pemerintah Indonesia menerbitkan ORI (Oeang Republik Indonesia). 
Didorong dengan terjadinya inflasi dan merosotnya kurs yang disebabkan oleh penggunaan mata uang Jepang dan NICA, percetakan uang berhasil mencetak emisi pertama ORI pada Oktober 1946 (Album Peringatan 45 tahun ORI, 11). Oeang Repoeblik Indonesia (ORI) dikeluarkan berdasarkan Undang-Undang No. 17 tahun 1946 ditetapkan pada 1 Oktober 1946 oleh presiden Soekarno dan mulai diedarkan tanggal 23 Oktober 1946 walaupun tanggal cetak yang tercantum 17 Oktober 1945. Emisi pertama Uang Republik Indonesia terdiri dari pecahan bernilai $1,5,10$, dan 50 sen. Selain itu pemerintah juga mengeluarkan emisi Uang Republik Indonesia pecahan bernilai 1, 5, 10, dan 100 rupiah. Emisi uang tersebut semuanya ditandatangani oleh Menteri Keuangan Republik Indonesia Mr. AA Maramis. Pada pecahan 1 (satu) sampai sepuluh rupiah bergambar wajah Presiden Republik Indonesia Ir. Soekarno. Media cetak tahun 1946 masih menggunakan ejaan lama yaitu OE untuk U. Uang Repulik Indonesia (ORI) yang diedarkan tanggal 23 Oktober 1946, ditetapkan oleh pemerintah pada tanggal 30 Oktober 1946. Pemerintah Republik Indonesia kemudian menetapkan tanggal 30 Oktober sebagai Hari Keuangan, dan sebagai hari penerbitan uang Republik Indonesia.

Wakil Presiden Muhammad Hatta yang berada di Yogyakarta menyambut gembira atas terbitnya Uang Republik Indonesia. Kegembiraan wakil presiden tersebut diungkapkan dalam pidatonya, yang berisi:

Besok tanggal 30 Oktober 1946 adalah soeatu hari jang mengandoeng sejarah bagi tanah air kita. Rakjat kita menghadap penghidoepan baroe. Besok moelai beredar oeang Republik Indonesia sebagai satoe-satoenya alat pembajaran jang sjah. Moelai pukul 12 tengah malam nanti, oeng Jepang jang selama ini beredar sebagai oeang jang sjah, tidak laku lagi. Beserta dengan uang Jepang itoe ikoet poela tidak lakoe oeang Javasche Bank. Dengan ini toetoeplah soeatoe masa dalam sedjarah keoeangan Repoeblik Indonesia. Masa jang penoeh dengan penderitaan dan kesoekaran bagi rakjat kita.

Sejak moelai besoek kita akan berbelandja dengan oeang kita sendiri, oeang yang dikeloearkan oleh Republik kita. Oeang repoeblik keluar dengan membawa peroebahan nasib rakyat, istimewa pegawai negeri, jang sekian lama menderita karena inflasi oeang Djepang. Roepiah Repoeblik jang harganja di Djawa lima poeloeh kali harga roepian Djepang. Di Soematera seratoes kali, menimboelkan sekaligoes tenaga pembeli kepada golongan rakjat jang bergadji tetap, jang selama ini hidoep dari pada mendjoal pakaian dan perabot roemah, dan djoega kepada rakjat jang menghasilkan, jang penghargaan toekar penghasilannja jadi bertambah besar. (Wiratsongko, 1991: 50)

ORI (Oeang Republik Indonesia) berhasil diedarkan dan ditetapkan melalui Undang-Undang menjadi uang milik negara Republik Indonesia, sekaligus menghentikan peredaran uang NICA yang beredar di Indonesia. Begitu pula uang kertas Jepang De Japanshce Regeering dengan sebutan gulden dan Jepang Dai Nippon dianggap tidak berlaku. Uang Republik Indonesia yang diterbitkan oleh pemerintah tersebut akhirnya dapat digunakan oleh masyarakat Indonesia sebagai alat pembayaran yang sah.

\section{Uridab (Uang Republik Indonesia daerah Banten)}

Setelah ibu kota pemerintahan berpindah dari Jakarta ke Yogyakarta, sebagian pemuda-pemuda pejuang yang tadinya berada di Jakarta pindah ke Tangerang (Michrob, 1993: 280). Dengan alasan mengejar musuh, pasukan NICA mengejar sampai Tangerang dan memerintahkan agar Kota Tangerang dikosongkan. Bagi Sekutu, Tangerang merupakan pintu menuju Banten. Tujuan Belanda melakukan blokade ekonomi untuk menyengsarakan rakyat agar putus asa terhadap 
pemerintah RI. Meskipun Belanda melakukan blokade ekonomi, namun keadaan rakyat tidak terlalu sengsara, sebab pemerintah Banten telah memperluas daerah pesawahan untuk mencukupi kebutuhan rakyat, sehingga blokade ekonomi Belanda tidak terlalu berpengaruh terhadap kebutuhan rakyat, karena bahan makanan tetap dapat tercukupi. Pada pertengahan tahun 1946, Banten telah menghasilkan garam sendiri, dan telah dibuka 12 ha tanah untuk pembuatan garam. Melalui 6 ha tanah, dapat menghasilkan garam sekitar 30 ton, sehingga kebutuhan akan garam dapat dipenuhi. Selain itu, juga dibuka pabrik minyak kelapa (Mexolie) dengan produksi sebulan menghasilkan 400 ton dan sebagian digunakan untuk eksport dan dibuka pertambangan yang fungsinya untuk memenuhi kebutuhan akan batubara. Dalam satu bulan dapat diproduksi sebanyak 50 ton, batu bara ini berfungsi menjalankan kereta api untuk perhubungan antara kota Banten guna mengangkut hasil bumi dari daerah pegunungan ke pelabuhan. Pertambangan Cikotok pun terus berjalan, dimana kebutuhan bensin dipenuhi dengan bensin yang terbuat dari karet (Nasution, 1978: 446).

Perindustrian tekstil juga dibangun di Serang hasilnya dapat memenuhi kebutuhan penduduk Kabupaten Serang. Di Cimanuk, Cibaliung, dan Bayah, rakyat mempunyai pertenunan sendiri di rumah. Kebutuhan penduduk di Pandeglang pun dapat terpenuhi dari pertenunan rakyat ini. Salah satu keuntungan di Banten adalah penghasil kopra yang mempunyai hubungan dagang dengan Jakarta yang dapat berjalan dengan lancar. Begitu pula hubungan dagangnya dengan Lampung. Dengan demikian, meskipun Banten mendapat blokade dari Belanda tetapi adanya industri kopra dapat menolong mereka.

Menjelang akhir tahun 1946, aktivitas operasi laut kapal-kapal Belanda di Selat Sunda mulai meningkat, sehingga kegiatan kapal Pulau Merak I dalam melakukan penyerangan dihentikan karena khawatir diserang patroli Belanda. Patroli angkatan Laut Belanda itu semakin meningkat menjelang dilaksanakannya Agresi Militer I. Adapun maksud dari patroli-patroli itu ialah untuk memblokir perekonomian Republik Indonesia, selain itu patroli juga mereka lakukan dengan pesawat-pesawat terbang yang seringkali melanggar batas wilayah kedaulatan RI (Madjiah, 1986: 108). Dalam Agresi Militer Belanda itu Komandan Brigade Tirtayasa Letkol Sukanda Bratamanggala menginstruksikan kepada para komandan sektor di Jakarta Barat, Serpong dan Bogor Barat agar mendahului menyerang pos Belanda di Tangerang dan sekitarnya yang dipimpin oleh para komandan sektor Jaelani. Sektor Jaelani mendapat bantuan dari tiga kompi pasukan yaitu kompi Umar Syarif dari Batalyon Polisi Tentara, Kompi Garuda yang disebut Kompi Strot Troep dibawah pimpinan Kapten Sabith, dan Kompi Pioner dibawah pimpinan Kapten Umar Dipokusumo. Kompi Pioner dilengkapi dengan bom menghancurkan beberapa bangunan dan jembatan strategis. Perintah komandan Brigade Tirtayasa itu dilaksanakan di seluruh sektor menjelang fajar, dipimpin para komandan sektor. Pada Sektor Jakarta Barat/Tangerang pertempuran berlangsung di Sepaten, Cimone, Kelapa Dua, dan Karawaci yang berlangsung dari fajar sampai petang hari. Dalam pertempuran itu sektor Jakarta Barat/ Tangerang mengalami kerugian beberapa prajuritnya gugur dan luka-luka.

Pasukan Belanda juga meningkatkan aktivitas kapal-kapal patroli di wilayah Banten dan Selat Sunda. Kapal-kapal patroli tersebut, baik berupa kapal darat atau pun laut. Dalam melakukan patroli tersebut, pasukan Belanda sering melanggar wilayah kedaulatan Republik Indonesia, sehingga suatu ketika menimbulkan suatu insiden. Insiden antar kedua belah pihak terjadi di wilayah Tangerang, front Parung Panjang, dan front Leuwiliang. Pada Agresi Militer yang dilancarkan pada tanggal 20 Juli 1947 tersebut, Belanda telah melakukan pendudukan dan penyerangan di daerah Tangerang dan sekitar 
Jakarta. Dengan adanya agresi tersebut maka komandan Brigade Tirtayasa Letkol Sukanda Bratamanggala menginstruksikan kepada para komandan sektor di Jakarta, Serpong, dan Bogor untuk mendahului penyerangan terhadap Belanda yang posisinya di Tangerang. Wilayah Tangerang mengalami beberapa titik pertempuran, yaitu di daerah Sepatan, Cimone, Kelapa Dua, dan Karawaci. Sepuluh hari setelah terjadinya perlawanan dari pejuang Banten kepada Belanda khususnya di wilayah Tangerang, akhirnya Belanda melakukan pembalasan. Dalam pembalasan tersebut Belanda melakukan penyerangan di Tangerang dan berhasil melakukan pendudukan, khususnya di daerah Sepatan, Jatake, dan Curug. Dengan adanya pendudukan Belanda tersebut, akhirnya pasukan Jaelani (yaitu komandan sector Jakarta/Tangerang) mengalami kekalahan dan mundur ke arah Cikupa. Dalam serangan pasukan Belanda tersebut, pasukan Jaelani mengalami kerugian hingga meninggalkan beberapa anggotanya yang gugur, dan 10 orang tertangkap Belanda. Meskipun pasukan Jaelani mundur ke arah Cikupa, hingga jumlah pasukan yang jauh ke belakang, namun pasukan ini berhasil melakukan penyusupan dan berhasil memukul mundur pasukan Belanda yang ada di Jatake. Dengan adanya peristiwa ini, hampir setiap hari terjadi pertempuran antara pejuang Banten dan Pasukan Belanda yang ada di sepanjang jalan Bitung-Cikupa. Dalam pertempuran tersebut, 20 pasukan TNI gugur dan pasukan lainnya luka-luka.

Akibat serangan Belanda terhadap daerah Tangerang tersebut, sejak tahun 1947 Belanda berhasil menguasai daerah Tangerang. Sebagai upaya untuk tetap menjalankan roda pemerintahan Kabupaten Tangerang, Bupati Tangerang memindahkan pusat pemerintahannya ke daerah Balaraja. Selain melakukan perang urat syaraf, pemerintah pendudukan Belanda melakukan taktik adu domba, yaitu dengan membentuk pasukan yang anggotanya terdiri dari bangsa Indonesia yang ditugaskan untuk melawan para pejuang. Salah satu pasukan buatan Belanda adalah pasukan divisi Banten dibawah pimpinan Sutan Akbar.

Tanggal 1 Agustus 1947, sepuluh hari setelah mendapat serangan dari pihak TNI, Belanda melakukan serangan balik sasarannya adalah sektor Jakarta/ Tangerang. Belanda mengerahkan tentara KNIL yang dilengkapi dengan kendaraan lapis baja. Serangan yang dilakukan dengan taktik melambung serta menyerang pasukan Jaelani dari samping dan belakang. Belanda pun berhasil menerobos pertahanan pasukan Jaelani, dan berhasil menduduki Jatake, Curug dan Sepatan. Pasukan Jaelani mundur ke Cikupa dan beberapa anggotanya gugur. Dalam Agresi Militer yang dilancarkan oleh Belanda, secara keseluruhan mengakibatkan pasukan TNI di tiga sektor itu terdesak mundur antara $10-15 \mathrm{~km}$ dari posisi semula. Di sektor Tangerang Barat, TNI kehilangan Curug, Sepatan, Jatake. Di sektor Parungpanjang, Belanda merebut Cisayur, Cisauk, dan Rumpin. Sementara, Belanda berhasil maju sampai Jambu dan Gobang (Erwantoro, 2002: 163). Meskipun pertempuran di perbatasan seringkali terjadi, tetapi tidak terus menembus Banten, Belanda lebih memusatkan perhatian ke Karesidenan Bogor, Priangan, dan Cirebon. Belanda kemudian melakukan blokade ekonomi, alat-lat militer, alat kesehatan dan obat, sehingga rakyat dan pasukan pejuang Banten merasa kesulitan dan menderita.

Dengan dikuasainya Kota Tangerang, blokade ekonomi oleh angkatan laut Belanda dilakukan. Dalam menghadapi blokade ekonomi tersebut, mereka bahumembahu mengatasi segala persoalan. Kekurangan bensin dapat diatasi dengan membuat bensin dari getah karet, sebagai ganti minyak pelumas digunakan minyak jarak dan minyak kelapa sawit. Minyak kelapa sawit juga digunakan untuk membuat salf, sebagai pengganti vaselin. Kekurangan senjata bisa diatasi dengan membuat mortir dan granat sendiri. Banyak penduduk yang harus mengguna- 
kan pakaian dari karung goni. Laki-laki menggunakan karung goni yang dibuat seperti celana. Sementara itu, sembilan bahan pokok kebutuhan hidup sehari-hari semakin sulit didapat. Pemerintah Indonesia yang berada di Yogyakarta putus hubungan dengan pemerintah daerah keresidenan di Banten, padahal segala kebutuhan rakyat harus terpenuhi.

Suasana perang yang terus berkecamuk menyebabkan sulitnya pengedaran ORI di beberapa wilayah tertentu. Langkanya ORI tersebut dikhawatirkan akan dimanfaatkan oleh NICA untuk mengedarkan mata uangnya. Oleh karena itu Pemerintah RI memberikan wewenang kepada Pemerintah Daerah tertentu untuk menerbitkan uang kertas atau tanda pembayaran yang sah yang berlaku secara terbatas di daerah yang bersangkutan. Penerbitan tersebut dijamin oleh Pemerintah dan pada waktunya dapat ditukar dengan ORI. Berdasarkan Peraturan Pemerintah No. 19/ 1947 tanggal 26 Agustus 1947, pemerintah daerah tingkat provinsi, keresidenan dan kabupaten menerbitkan Uang Republik Indonesia Daerah yang dikenal dengan URIDA. Pada awal peredaran ORI setiap penduduk diberikan satu rupiah ORI untuk mengganti sisa uang Jepang yang masih dapat dipakai sampai 16 Oktober 1946, yaitu tanggal ditetapkannya penukaran simpanan di Bank dengan ORI.

Untuk memenuhi kebutuhan dan alat pembayaran yang sah di daerah, maka pemerintah pusat di Yogyakarta memerintahkan Residen Banten K.H. Achmad Chatib untuk mencetak dan mengeluarkan Uang Kertas Darurat Daerah Banten (URIDAB), khusus untuk wilayah Banten yang termasuk Tangerang, Jasinga, dan Lampung Selatan. Setelah ada persetujuan dari pemerintah pusat, bahwa Serang Banten dijadikan sebagai tempat mencetak Uang Republik Indonesia Daerah melalui Residen Banten Kiai Haji Achmad Chatib, maka mulailah dilakukan pencetakan uang yang diberi nama URIDAB. Percetakan URIDAB meliputi pecahan 1, 5, 10, 25 rupiah. Pecahan tersebut dicetak dalam jumlah yang tidak terhitung. Masa pencetakan URIDAB dari Februari sampai 11 Agustus 1948.

Mata uang bernilai 1 (satu) rupiah dibuat dari bahan dari kertas berwarna dasar coklat muda berukuran $13 \times 6,5 \mathrm{~cm}$, warna bingkai dan gambar didominasi oleh warna pink dan beberapa tulisan berwarna

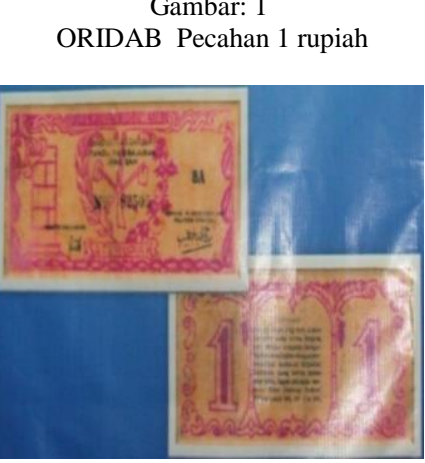

Sumber: Penelitian 2011

hitam. Sisi depan mata uang bagian tengah bawah bertuliskan satu rupiah. Di atas tulisan satu rupiah terdapat gambar padi dan kapas yang melingkari gambar senapan cangkul dan palu, tulisan uang kertas "DARURAT TANDA PEMBAJARAN JANG SAH" serta nomor seri. Pada sebelah kanan terdapat tulisan angka "1". Mata uang tersebut dikeluarkan di Serang pada 15 Desember 1947 ditandatangani oleh Panitia Keuangan dan Residen Banten. Pada bagian belakang mata uang, ditengahnya terdapat dua pohon pinang yang mengapit peringatan hukuman bagi pemalsuan mata uang yang diatur dalam Kitab Undang-Undang Hukum Pidana pasal 244, 245, 249. Selain itu, di sisi belakang juga terdapat angka satu dari kiri dan kanan pohon pinang. 
Selain bernilai satu rupiah, mata uang pecahan terdapat pula yang bernilai lima (5) rupiah. Uang ini terbuat dari kertas berwarna dasar putih berukuran 14 $\mathrm{x} 7,5 \mathrm{~cm}$. Warna bingkai gambar dan Gambar: 2 ORIDAB Pecahan 5 rupiah

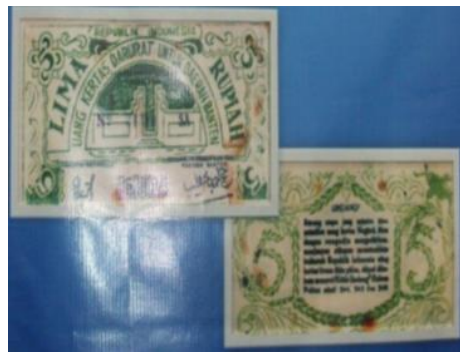

Sumber: Penelitian 2011

tulisan didominasi warna hijau serta beberapa tulisan berwarna hitam. Di sisi depan mata uang, pada bagian tengah atas terdapat tulisan "REPUBLIK INDONESIA". Tulisan 5 rupiah, tulisan Uang Kertas Darurat untuk daerah Banten dalam bingkai garis setengah lingkaran, di bawah bingkai garis ini terdapat gambar pintu gerbang, nomor seri dan tulisan "TANDA PEMBAJARAN JANG SAH". Keempat sudut sisi depan mata uang yang bernilai lima rupiah tersebut tertulis angka"5". Mata uang tersebut dikeluarkan di Serang 15 Desember 1947 ditandatangani oleh panitia keuangan dan Residen Banten. Pada bagian belakang mata uang didominasi warna hijau

gambar padi, burung, dan dua tulisan angka 5. Pada bagian tengah terdapat peringatan hukuman bagi pemalsu mata uang yang diatur dalam Kitab Undang-Undang Hukum Pidana pasal $244,245,249$.

Mata uang bernilai sepuluh rupiah (Rp. 10) berbahan kertas berwarna dasar putih berukuran $15,5 \times 6 \mathrm{~cm}$. Warna bingkai gambar tulisan didominasi warna Gambar: 3

ORIDAB Pecahan 10 rupiah

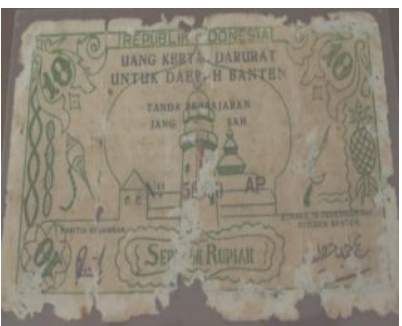

hijau serta beberapa tulisan berwarna hitam. Pada mata uang bagian depan, pada tengah-atas terdapat tulisan "REPUBLIK INDONESIA". Di bawah tulisan tersebut tertulis "uang kertas darurat untuk daerah Banten". Pada bagian tengah terdapat gambar kubah dan masjid Agung

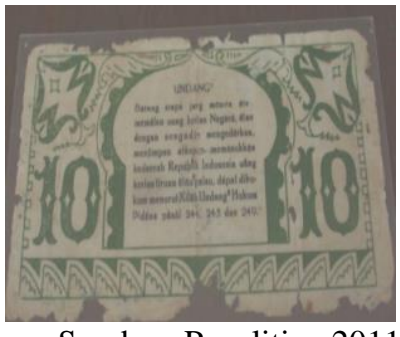

Sumber: Penelitian 2011

Banten lengkap dengan bangunan, menara, dan tiamah, nomor seri dan tulisan "TANDA PEMBAJARAN JANG SAH" di kiri dan kanan kubah dua jenis senjata yakni di sebelah kiri debus dan di sebelah kanan keris. Selain kedua senjata tersebut terdapat buah rambutan dan nanas. Nilai angka terdapat pada tiga sudut, dua sudut di atas dan satu di bawah sudut kiri. Sementara, di bawah sudut kanan terdapat tanda tangan Residen Banten. Pada bagian mata uang tesebut juga terdapat empat binatang unggas, yakni dua di dua sudut kiri atas dan dua di sudut kanan atas. Sementara, di bagian belakang mata uang tersebut terdapat dua angka: "10" hiasan pinggir. Pada bagian tengah terdapat gambar kubah didalamnya bertuliskan peringatan hukuman bagi pemalsuan mata uang seperti yang diatur dalam Kitab Undang-Undang Hukum Pidana pasal 244, 245, dan 249. 
Mata uang bernilai 25 (dua puluh lima) rupiah, terbuat dari kertas, berwarna dasar putih, berukuran $14 \times 7,5 \mathrm{~cm}$, bingkai, gambar dan tulisam keseluruhan merah kecuali nomor seri berwarna hitam. Pada sisi depan mata uang, di bagian

Gambar: 4

ORIDAB Pecahan 25 rupiah
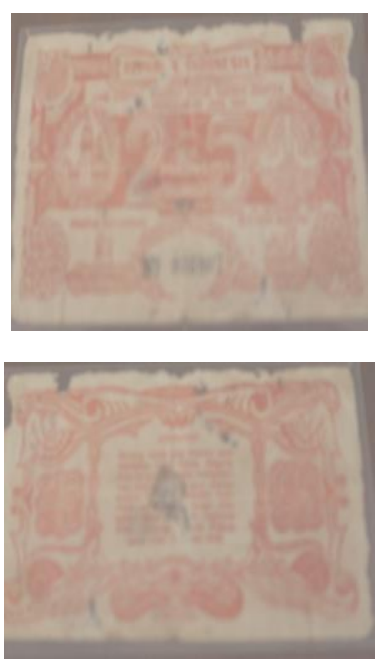

tengah atas terdapat tulisan "REPUBLIK INDONESIA" dikelilingi sebuah bingkai. Pada sebelah kiri terdapat gambar menara dan masjid agung dalam lingkaran padi. Sebelah kanan gambar terdapat gapura Kaibon dalam lingkaran padi. Pada bagian tengah terdapat angka " 25 " di antara angka 25 terdapat tulisan "dua puluh lima". Pada sudut kiri dan kanan atas serta bawah, ada angka 25 dengan posisi menghadap ke dalam, masing-masing ada di lingkaran ular. Adapun di bagian belakang mata uang terdapat dua buah angka " 25 "; di kanan dan kiri. Pada hiasan pinggir terdapat gambar berbagai flora. Pada bagian tengah terdapat peringatan hukuman bagi pemalsuan mata uang yang diatur dalam kitab undang-undang hukum pidana pasal 244, 245, dan 249.

Pada dasarnya setiap mata uang yang dibuat di Serang Banten tersebut terbuat dari bahan dasar kertas. Namun demikian, karena suasana masih dalam Agresi Militer II, maka bahan dasar kertas tersebut didatangkan dari luar secara sembunyi-sembunyi. Selain pecahan 1, 5, 10, dan 25 rupiah, Banten juga mencetak pecahan 100 rupiah bahan dasar terbuat dari timah. Pembuatannya dilakukan oleh pemerintah daerah Banten. Akan tetapi uang pecahan tersebut belum tersebar karena terjadi Agresi Militer ke Banten oleh pihak Belanda.

Pembuatan mata uang ORIDAB dilakukan oleh pemerintah daerah Banten dan dilaksanakan secara gotong-royong. Alat yang digunakan berupa alat cetak sederhana maka uang tersebut dapat diperbanyak dengan jumlah yang tidak diketahui. Cara pembuatannya, sebelum uang tersebut dicetak terlebih dahulu dibuat gambar yang akan ditampilkan. Gambar tersebut dibuat oleh E. Edel Yusuf di Serang. Klisenya dibuat oleh M. Ruyani dan Dana, kedua-duanya di Kecamatan Petir, bahan klise tersebut dari kayu sawo, kecuali untuk pecahan 100 rupiah dibuat dari timah. Mesin cetak pembuatan uang tersebut sampai sekarang disimpan di Museum Banten Lama. Percetakan ORIDAB dilaksanakan di Jalan Diponegoro No. 6 Serang. Pemilik percetakan bernama Abdurrojak. Percetakan uang dipimpin oleh R. Abubakar Winangun M. Sastra Atmadja, Abdurrojak, dan M. Solihin. Pejabat penerima, penyimpan, dan pengedaran uang kertas adalah M. Ismail. Mereka diangkat berdasarkan Surat Ketetapan Kepala Pejabatan Keuangan Dewan Pertahanan Daerah Banten No. UU/94 tanggal 26 Mei 1948. Ahli dan karyawan percetakan berjumlah 11 orang, lima orang di antaranya yaitu Muhamad Jupri, Suparman, Muhamad Tohir, Senen, dan Sanah. Pada tahun 1948 URIDAB ditandatangani oleh K.H. Achmad Chatib dan Yusuf Adiwinata sebagai Kepala Pejabat Keuangan Dewan Pertahanan Daerah Banten. KH. Achmad Chatib yang menjabat sebagai Residen Banten bercita-cita untuk menyejahterakan rakyatnya. Selain itu Keresidenan Banten mempunyai hubungan dagang dengan Pulau Sumatera baik dalam ekspor maupun impor, untuk itulah diperlukan perputaran 
uang untuk menopang perekonomian tersebut. Banten merupakan lahan pertanian yang subur. Untuk meningkatkan pendapatan kas karesidenan, pertanian pun dapat menopang perekonomian Keresidenan Banten. URIDAB ini juga digunakan untuk membayar gaji pegawai. URIDAB ini wujudnya sangat sederhana sehingga mudah dipalsukan. Sementara itu percetakan URIDAB dilakukan secara terus menerus sehingga menimbulkan inflasi di Banten.

Pada bulan Februari 1949, perhubungan antar kota di Banten sukar dan tidak aman, URIDAB mulai sulit didapat. Di pasar-pasar diberlakukan sistem barter. Sulitnya URIDAB tersebut dikarenakan masyarakat yang berada di pedesaan hanya mau menerima URIDAB sebagai alat tukar. Sementara, Tentara Belanda justru menggunakan uang NICA untuk alat tukar mereka.

Saat terjadinya Agresi Militer II, 19 Desember 1948, tentara Belanda melakukan perampasan pecahan uang 100 rupiah, sehingga uang pecahan tersebut belum sempat ke tangan masyarakat. Selain uangnya, Belanda juga melakukan perusakan seluruh klise pembuatan uang pecahan 100 rupiah tersebut. Saat itulah URIDAB dibekukan oleh Belanda dan tidak diperbolehkan beredar.

\section{PENUTUP}

Diterbitkannya Uang Republik Indonesia Daerah Banten adalah akibat adanya blokade ekonomi yang dilakukan oleh pasukan Sekutu terhadap daerah Banten. Alasan Sekutu melakukan blokade ekonomi disebabkan wilayah Jakarta Tangerang melakukan perlawanan terhadap tentara Sekutu dan menghancurkan beberapa bangunan penting milik pemerintah Belanda serta jembatan yang lokasinya strategis. Dalam membalas serangan yang dilakukan para pejuang Banten, pasukan Sekutu tidak langsung menembus masuk Kabupaten Serang, namun menyerang wilayah pinggiran, berikutnya Sekutu melakukan blokade ekonomi dan memu- tuskan komunikasi. Saat itulah Keresidenan Banten putus komunikasi dengan pemerintah pusat yang berada di Yogyakarta, sehingga Ir. Soekarno menginstruksikan kepada Residen Banten K.H. Achmad Chatib untuk mencetak uang daerah agar dapat digunakan untuk kebutuhan warga Banten.

Uang yang dicetak bernilai 1, 5, 10, dan 25 rupiah. Keempat jenis mata uang tersebut ditandatangani oleh resien Banten KH Achmad Chatib. Pada saat Banten akan mencetak uang bernilai 100 rupiah, Belanda melakukan perusakan klise pembuatan uang 100 rupiah. Tidak lama kemudian Belanda pun membekukan dan melarang peredaran URIDAB.

\section{DAFTAR SUMBER}

\section{Sumber Buku}

Ekadjati, 1993.

Sejarah Pemerintahan di Jawa Barat. Bandung: Pemerintah Daerah Provinsi Tingkat I Jawa Barat.

Ensiklopedi Nasional Indonesia. Jilid 3. 1989.

Jakarta: Cipta Adi Pustaka.

Erwantoro, Heru. 2002.

Pergolakan Revolusi Sosial di Keresidenan Banten (1945-1949). Jurnal Penelitian. Bandung: Balai Kajian Sejarah dan Nilai Tradisional Bandung.

Kertorahardjo, Haris. 2009.

Seri Lawas Uang Kuno. Jakarta:

Kepustakaan Populer Gramedia bekerjasama dengan Bentara

Budaya.

Kutoyo, Sutrisno, 1997

Sejarah Daerah, Daerah Istimewa Yogyakarta. Jakarta: Departemen Pendidikan dan Kebudayaan RI, Proyek Pengkajian dan Pembinaan 
Sejarah dan Nilai Tradisional, Direktorat Jenderal Kebudayaan.

Michrob, Halwany dan Chudari, Mudjahid. 1993.

Catatan Masa Lalu Banten. Serang: Saudara.

Moeliono, Anton. M, 2011.

Kamus Besar Bahasa Indonesia, Pusat Bahasa, Departemen Pendidikan Nasional. Jakarta: Gramedia Pustaka Utama.

Nasution, A.H. 1977.

Sekitar Perang Kemerdekaan Indonesia, 1: Proklamasi. Bandung: Disjarah AD dan Angkasa.

1977.

Sekitar Perang Kemerdekaan Indonesia, 2: Diplomasi atau Bertempur, Bandung: Disjarah AD dan Angkasa.

1978.

Sekitar Perang Kemerdekaan Indonesia, 5: Agresi Militer Belanda I. Bandung: Disjarah $\mathrm{AD}$ dan Angkasa.

Notosusanto, Nugroho (editor). 1975.

Sejarah Nasional Indonesia, VI,

Jaman Jepang dan Jaman Republik Indonesia. Jakarta: Departemen Pendidikan dan Kebudayaan.

Sastrosatomo, Subagio, 1987.

Perjuangan Revolusi. Jakarta: Pustaka Sinar Harapan.

Suharto, 2009.

Banten Pasca Agresi Militer Belanda Kedua, Makara, Sosial Humaniora, Vol. 13. No. 2. Desember 2009: 85-90, Universitas Indonesia, Depok.

\section{Sumber Elektronik}

http/l: www. blok-anak-sekolah.blogspot. com dalam: Makalah Revolusi Banten diakses: 1 Agustus 2012

http://duniabaca.com.

dalam: sejarah uang

diakses: 1 Agustus 2012 